\title{
Uma aula sobre Medicina Alternativa em língua estrangeira
}

\section{Teaching Alternative Medicine in English}

\author{
Greicy Bellin*
}

No primeiro semestre de 2007, cursei a disciplina de Metodologia do Ensino de Anglo-Germânicas, com o professor Henrique Evaldo Janzen. Como parte do processo de avaliação, nos foi solicitada a elaboração de um tópico de uma unidade temática, ou seja, parte de uma lição em língua inglesa, e o assunto do tópico seria de nossa escolha. Como eu havia feito um tratamento com acupuntura, e obtive os resultados que eu desejava, resolvi criar um tópico sobre medicina alternativa, pois considero esse assunto muito interessante e pouco explorado. De fato, a maioria dos livros didáticos de inglês explora o assunto saúde de forma muito repetitiva, sempre enfocando a medicina tradicional e nunca a medicina alternativa. Um dos únicos livros disponíveis no Centro de Recursos do Celin que trata de medicina alternativa é o Skyline $3 B$, que por sinal era o material didático utilizado no curso de inglês até o primeiro semestre de 2008. A imensa maioria dos livros que temos para consulta se limita a discorrer sobre doenças, sintomas, formas de tratamento e medidas de prevenção das doenças dentro da perspectiva da medicina tradicional, sem abordar nada relativo às medicinas alternativas, tais como acupuntura, homeopatia, florais, quiropraxia, e outras. Minha idéia era trabalhar comunicativamente com esse tópico, criando situações nas quais os alunos pudessem praticar a escrita e a oralidade partindo de seus conhecimentos de mundo e explorando suas crenças sobre saúde de uma forma estimulante.

A abordagem comunicativa surgiu por volta da década de 70, a partir da necessidade de um método mais eficaz, que "levasse as pessoas a dominarem não apenas o conhecimento gramatical de línguas estrangeiras que tivessem de aprender, mas que pudessem usar adequadamente estas línguas em situações reais de interação social” (SILVEIRA, 1999: p.74). Desta forma, a língua é vista como um instrumento a ser utilizado nas mais diversas situações sociais, possibilitando ao aluno utilizar suas "estratégias de aprendizagem durante as atividades propostas e construir os seus conhecimentos através da interação com os colegas e com o professor" (SILVEIRA, 1999: p.77). Dentro desta abordagem, os conteúdos são

\footnotetext{
* Greicy Bellin é aluna do Programa de Pós-graduação em Letras da Universidade Federal do Paraná e professora de inglês no Centro de Línguas e Interculturalidade da mesma universidade.
} 
organizados a partir de uma seleção de tópicos, evitando a repetição e os exercícios mecânicos. Privilegia-se a apresentação de situações-problema, nas quais os alunos irão usar seus conhecimentos de mundo para desenvolver sua competência comunicativa, fugindo assim da monotonia da abordagem tradicional, que consiste no aprendizado das regras gramaticais, com muito pouca ênfase em situações de comunicação real.

Dentro dos estudos sobre aquisição de segunda língua, multiplicam-se as evidências de que a abordagem comunicativa é eficaz no aprendizado de línguas estrangeiras. Prova disso é que a maioria dos cursos formais de instrução em língua inglesa utiliza tal abordagem, em virtude da necessidade cada vez maior de se aprender a falar o inglês em um mundo globalizado. Na visão de LIGHTBOWN e SPADA (1999, p.43), muito da aquisição de segunda língua se dá através da interação conversacional, pois os alunos se engajam em "negociações de sentido" que fazem com que cheguem a um entendimento mútuo acerca do tópico que estão discutindo. As pesquisas mostram que isso é extremamente importante para o aprendizado da segunda língua, no sentido de que obriga os alunos "expressar e clarificar suas intenções, pensamentos e opiniões, (...) levando-os a adquirir as formas lingüísticas que carregam o significado que eles procuram" (LIGHTBOWN \& SPADA, 1999: p.122). Comentando uma série de experimentos conduzidos em sala de aula, as autoras salientam que os alunos mais empenhados em interações conversacionais produzem formas lingüísticas mais avançadas do que aqueles que não se aventuram a praticar a oralidade. De fato, isso mostra como a abordagem comunicativa é eficiente no aprendizado de uma língua estrangeira, ajudando a desenvolver a fluência e o "jogo de cintura" que são exigidos para se comunicar em situações reais de uso do idioma.

Partindo dos pressupostos mencionados acima, pensei que seria uma boa idéia aplicar o tópico em sala de aula, e eis que surge a grande oportunidade no semestre seguinte, enquanto cursava a disciplina de Prática de Ensino e Estágio Supervisionado, também com o professor Henrique. Como ensino inglês no Celin da UFPR, e sendo esta uma escola de aplicação, achei que seria possível ministrar o tópico sem grande choque por parte dos alunos. O assunto fazia parte do conteúdo programático do semestre, no nível Pré Intermediário II, e como o livro Skyline 3B não oferecia exercícios suficientemente interessantes, resolvi aplicar o plano de aula, pois achei que seria uma boa oportunidade para fugir da rotina do livro e discutir em sala um assunto muito pouco explorado.

O plano consiste de cinco partes. A primeira é uma revisão, com um teste sobre saúde e uma figura do corpo humano, com espaços em branco para que o aluno preencha com palavras referente às partes do corpo. O objetivo da revisão era realizar um "warm up", 
colocando os alunos em contato com o tema a partir de seu conhecimento de mundo. Os alunos reagiram com dificuldades, pois muitos não se lembravam das partes do corpo humano em inglês. Uma aluna chegou até mesmo a comentar: "Não sei como se fala em português, como vou saber em inglês?" Isso me pareceu muito interessante, pois mostra como o desconhecimento em relação à língua materna influencia o aprendizado da língua estrangeira. Creio que o exercício foi bastante oportuno, porque obrigou os alunos a se lembrarem das partes do corpo, e os que não sabiam as palavras acabaram aprendendo o significado delas de forma contextualizada, o que facilita a retenção na memória. Além disso, os alunos se saíram bem no teste sobre saúde, retirado do livro American Inside Out B, que por sinal é agora o material didático utilizado na área de inglês do Celin. Tal teste contém perguntas básicas sobre saúde, prática de exercícios, tabagismo e outros hábitos perigosos, com um score final que indica a qualidade do estado de saúde do aluno e que permite a ele/ela pensar no assunto de uma forma divertida, interagindo com os outros colegas na comparação dos resultados. Desta forma, os alunos iniciaram a discussão do tópico partindo de suas próprias experiências de vida, o que tornou o debate muito mais interessante a inserido dentro da realidade deles.

A segunda atividade consistia em um exercício de associação, no qual os alunos deviam relacionar problemas de saúde a soluções caseiras. O objetivo da atividade era introduzir o assunto medicina alternativa de uma forma que obrigasse os alunos a usar seu conhecimento de mundo, empregando funções comunicativas para dar conselhos, e de fato este objetivo foi atingido. Os alunos se empolgaram bastante dando conselhos, relatando várias histórias engraçadas. Descobri que em Florianópolis, SC, as pessoas usam pinga para curar mordidas de inseto. $\mathrm{O}$ assunto acabou rendendo boas gargalhadas, além da certeza de que vale a pena incitar os alunos a lançarem mão de seu conhecimento de mundo. Isso torna as aulas muito mais interessantes e empolgantes. Segue abaixo uma cópia do exercício, que foi baseado em uma lição do livro New Interchange $2 B$.

\begin{tabular}{|c|c|}
\hline \multicolumn{2}{|c|}{$\begin{array}{l}\text { Match the words and expressions below with the pieces of advice that your grandmother would } \\
\text { give about health. }\end{array}$} \\
\hline Insect bites & Eat a hot chicken soup. \\
\hline Burns & Apply an ice pack \\
\hline Colds & Drink a glass of warm milk \\
\hline Cough & Eat garlic or take pills. \\
\hline Headaches & Apply a cabbage leaf. \\
\hline Insomnia & Put ice or aloe vera gel \\
\hline Sore Muscles & Drink warm liquids \\
\hline
\end{tabular}


A terceira atividade consistia em um listening sobre homeopatia. Os alunos deveriam ouvir e preencher vários espaços em branco com informações relevantes de uma entrevista com uma médica homeopata. Esta parte da lição foi muito trabalhosa, pois a maioria dos alunos adultos apresenta dificuldades com listening. Foi necessário repetir o exercício três vezes, pois a entrevista continha vários termos técnicos da área de homeopatia. Havia ainda um trecho da entrevista no qual a médica falava muito rápido, e fiz questão de pausá-lo e escrever algumas passagens no quadro para que não restassem dúvidas. Por fim, repeti a entrevista mais uma vez, e os alunos ficaram realmente interessados no assunto, chegando até mesmo a me perguntar detalhes sobre homeopatia. Tive que responder: "I am a teacher, not a homeophatic practitioner!" É interessante a confiança que os alunos depositam na figura do professor, que dentro dos pressupostos da abordagem comunicativa se torna um informante não só dos itens lingüísticos a serem adquiridos, mas também do conhecimento específico que estava sendo exigido no exercício. (SILVEIRA, 1999: p. 77). Isso foi muito estimulante para mim, pois acabei me empenhando em uma pesquisa sobre homeopatia, o que acabou melhorando o meu conhecimento de mundo. Para os alunos, creio que foi mais proveitoso ainda, pois eles treinaram o listening, algo considerado difícil, com um assunto que pouco conheciam, o que lhes rendeu mais conhecimento e mais vocabulário. Esta atividade foi retirada do livro Skyline $3 B$.

Listen to an interview with a homeopathic practitioner and complete the spaces with information from what you listen:

Homeopathy was developed by a in

It was introduced into U.S in By the end of the 19th century ___ $\%$ of American doctors were homeopathic practitioners.

Homeopathy is based on two principles:

1

2

Number of people using homeopathy in the U.S:

Homeopathic remedies are useful for asthma, allergies, and

\section{Transcrição do áudio apresentado em sala}

Interviewer: Adriana, what exactly is homeopathy?

Adriana: Well, it's a system of medicine that uses medicines made from diluted extracts of herbs and other natural substances.

Interviewer: And who developed this system?

Adriana: A German doctor named Samuel Hahnemann in 1796.

Interviewer: A German doctor?

Adriana: That's right. Homeopathy was introduced into the U.S. in 1825 . By the end of the $19^{\text {th }}$ century about $15 \%$ of American doctors were homeopathic practitioners.

Interviewer: What's the theory behind homeopathy? 
Adriana: Homeopathy is based on two main principles. The first says that a substance that can give a healthy person symptoms of an illness can actually cure that illness in a sick person.

Interviewer: That's strange - something that can make a normal person ill can help make a sick person better? Adriana: Yes. The second principle says that the more a substance is diluted, the more potent it becomes.

Interviewer: That's really interesting - so a homeopathic remedy contains only a very small amount of the substance?

Adriana: That's right.

Interviewer: I see. How many people use homeopathy today?

Adriana: Well, in the U.S. about 2,5 million people use it regularly.

Interviewer: Really? And can homeopathy cure anything?

Adriana: Well, it makes you feel better generally, but it's especially useful for asthma, allergies, diarrhea and migraine.

A quarta parte da lição era a parte de leitura. Resolvi usar dois textos pequenos, porque achei que um texto grande seria mais difícil de trabalhar. Escolhi um texto sobre acupuntura, e outro sobre homeopatia. Na sequiência, propus duas atividades, uma de compreensão global, com várias sentenças retiradas dos textos, na qual os alunos deveriam relacionar as informações a um texto ou outro, e uma atividade que o professor Henrique chama de "fluxograma". Esta atividade consiste em uma nova versão dos dois textos, só que com espaços em branco, para que os alunos preencham com palavras-chave do próprio texto, sem olhar no original. Seguem abaixo um dos textos e o fluxograma.

\section{TEXT ONE - ACUPUNTURE}

Acupunture is a treatment for pain and illness. It treats the human body as a whole that involves several systems of function, that are in some cases associated with physical organs. The disease is understood as a loss of balance between the ying and yang energies among the systems of function, and treatment of disease is made by changing the activity of one or more systems through the application of needles on sensitive parts of the body called acupunture points. Besides, Chinese medical theory claims that acupunture works by normalizing the free flow of the qi energy throughout the body. Pain or illnesses are treated by trying to remedy local or systemic accumulations or deficiencies of energy. They consider that pain indicates stagnation of $q i$.

The treatment is very simple. The acupunturist decides which points to treat by observing and questioning the patient in order to make a diagnosis according to the tradition he or she follows. The main points of acupunture are located in the hands, the head and the feet.

FLUXOGRAM - Fill in the blanks with the appropriate words:

Acupunture is a treatment for pain and illness. It treats the human body as a whole that involves several systems of function, that are in some cases associated with organs. The disease is understood as a loss of __ between the ying and yang energies among the systems of function, and treatment of disease is made by changing the o fone or more systems of function through the application of on sensitive parts of the body called acupunture

Besides, Chinese medical

theory claims that acupunture works by normalizing the free

Pain or illnesses are treated by trying to of the qi energy throughout the body. energy. They consider that pain indicates stagnation of qi.

The treatment is very simple. The decides which points to treat by observing and questioning the in order to make a diagnosis according to the tradition he or she follows. The main point of acupunture are located in the , the and the 
Esta atividade foi muito difícil para os alunos, acostumados a aprender vocabulário de forma descontextualizada, usando simplesmente o dicionário, e limitando-se a memorizar o significado da palavra sem entender como ela funciona em contexto. A tentação de olhar no original era muito grande; pois eu havia pedido que eles não olhassem; e alguns alunos nem mesmo realizaram a atividade, pois não se consideravam capazes de relembrar as palavras. Os alunos também queriam saber a tradução das palavras, procedimento este que evitei, recorrendo à paráfrase e ao uso da lousa para desenhar os itens quando parecia não haver jeito de explicar o que a palavra significava. Mas ao final da atividade, todos acabaram conseguindo realizar o exercício, com a certeza de que é mais proveitoso aprender as palavras em contexto do que de forma solta.

A quinta e última atividade era uma proposta de escrita. Os alunos deveriam escrever um e-mail para um amigo, relatando um suposto tratamento com medicina alternativa. $\mathrm{O}$ que mais predominou foi, sem dúvida, acupuntura e homeopatia. Os alunos mais uma vez foram requisitados a lançar mão de seu conhecimento de mundo, relatando casos reais, como por exemplo, o de uma aluna que fez um tratamento homeopático para uma doença alérgica de pele. Ao mesmo tempo, também foram relatados casos inverídicos, como o deste aluno, que me enviou a lição por e-mail com a seguinte declaração: "história fictícia, baseada em informações não reais". A meu ver, isto é um dado muito interessante, pois mostra que, mesmo não tendo vivido a situação descrita, o aluno é capaz de evocar o conhecimento de mundo necessário para descrevê-la na língua estrangeira, tornando seu aprendizado muito mais proveitoso.

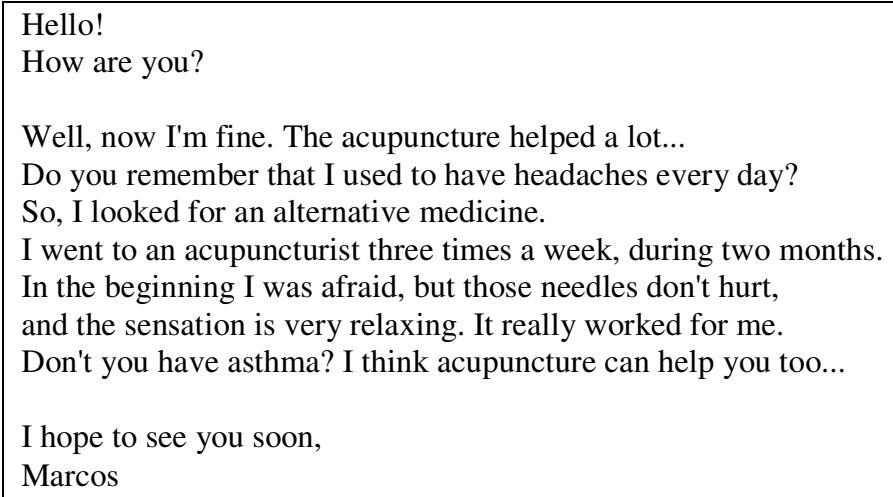

Por fim, considero que a experiência foi extremamente positiva, pois me mostrou como é estimulante deixar os alunos à vontade para explorar seu conhecimento de mundo na língua estrangeira, praticando com isso a oralidade e a escrita de forma extensiva e proveitosa, 
o que lhes deu mais segurança no uso da língua. Acredito que é sempre importante insistir na comunicação em contextos reais para se aprender um idioma, porque isso deixa os alunos muito mais livres para ousar no aprendizado da língua, e muito mais seguros para usá-la quando tiverem necessidade. Creio que as atividades propostas atingiram este objetivo, pois deram aos alunos a oportunidade de praticar o idioma e desenvolver estratégias cognitivas associadas a um tema muito pouco explorado nas aulas de língua estrangeira.

\section{Referências}

LIGHTBOWN, Patsy M; SPADA, Nina. How languages are learned. Cambridge University Press, 1999.

SILVEIRA, Maria Inês Matoso. Línguas Estrangeiras: uma visão histórica das abordagens, métodos e técnicas de ensino. São Paulo: Catavento, 1999. 